\title{
Recent advances in application of chitosan in fuel cells
}

\author{
Hamideh Vaghari ${ }^{1}$, Hoda Jafarizadeh-Malmiri ${ }^{1 *}$, Aydin Berenjian $^{2}$ and Navideh Anarjan ${ }^{3}$
}

\begin{abstract}
Fuel cells are electrochemical devices which convert chemical energy into electrical energy. Fuel cells have attracted attention due to their potential as a promising alternative to traditional power sources. More recently, efficient and environmentally benign biopolymer "chitosan" have been extensively investigated as a novel material for its application in fuel cells. This biopolymer can be used in both membrane electrolyte and electrode in various fuel cells such as alkaline polymer electrolyte fuel cells, direct methanol fuel cells and biofuel cells. This review provides an overview of main available fuel cells following by application of chitosan as novel biopolymer in fuel cells technology. Recent achievements are included and recommendations are also given for areas of future research.
\end{abstract}

Keywords: Fuel cell, Chitosan, Electrolyte membrane, Electrode, Polymer

\section{Introduction}

The extensive use of fossil fuels has resulted to severe pollutant emissions, including $\mathrm{SO}_{\mathrm{x}}, \mathrm{NO}_{\mathrm{x}}, \mathrm{CO}$, and particulates which pose severe threat to the health of human beings [1]. In addition, a steady depletion of world's limited fossil fuel, reserves calls for efficient, benign and sustainable technologies for energy conversion and power generation. Fuel cells are among the most efficient and environmental friendly devices for energy conversion and power generation due to their zero-emission power source [2]. Fuel cells have been identified as one of the most promising and potent technologies which meet energy security, economic growth, and environmental sustainability requirements [2]. Although fuel cell technology has matured substantially over the past decades, technological barriers, such as insufficient durability, cell life time and fuel cell component costs, still delay commercialization in many applications [3]. There are different types of fuel cells that are generally characterized by electrolyte material. Among electrolyte material, solid polymer-based electrolyte membranes offer advantages such as high efficiency and high energy density [4]. However, polymer electrolyte membrane is the most expensive component of a polymer electrolyte-based fuel cell [5]. Therefore, cost effective and eco-friendly

\footnotetext{
* Correspondence: h_jafarizadeh@sut.ac.ir

'Department of Chemical Engineering, Sahand University of Technology, Tabriz, Iran

Full list of author information is available at the end of the article
}

polymer electrolytes from renewable sources can become a promising substitute for synthetic polymers in fuel cells. Among natural polymers, polysaccharides are among the best candidates due to their abundance in environment [5]. Chitosan, as a derivative of chitin, is a naturally abundant and low-cost biopolymer which has attracted attention in various scientific and engineering processes due to its excellent biocompatibility, non-toxicity and chemical and thermal stability [6-8]. The presence of amino groups in the glucosamine residue imparts an additional characteristic feature to chitosan in comparison to these polysaccharides. The positive charge arising due to the highly protonated amino functionalities enables chitosan to form polyelectrolyte complexes spontaneously with a wide variety of negatively charged polyanions such as lipids, collagen, glycosaminoglycans, lignosulfonate, and alginate, as well as charged synthetic polymers and DNA through electrostatic interaction [4,7]. The objectives of the present review are to investigate the current status of fuel cells and advances in utilization of chitosan biopolymer for polymer electrolyte membrane technologies.

\section{Fuel cells}

\section{Fuel cells-relevance and importance}

Fuel cells are environmental friendly devices for energy conversion, power generation, and one of the most promising candidates as zero-emission power sources [2]. Fuel cells are electrochemical devices which convert the 
chemical energy obtained from a redox reaction directly into electrical energy [5]. These cells consist of an electrolyte material that is packed between two thin electrodes (porous anode and cathode). The input fuel passes over the anode and oxygen passes over the cathode where they are dissociated catalytically into ions and electrons. The electrons pass through an external electrical circuit to provide power while the ions move through the electrolyte toward the oppositely charged electrode [2,4].

\section{Fuel cells classification and engineering}

Fuel cells are generally characterized by the type of electrolyte material. These cells are mainly consisted of: Alkaline Fuel Cell (AFC), Molten Carbonate Fuel Cell (MCFC), Phosphoric Acid Fuel Cell (PAFC), Proton Exchange Membrane Fuel Cell (PEMFC), Solid Oxide Fuel Cell (SOFC), and Biofuel Cell $[9,10]$. Figure 1, compares and illustrates the prominent features of these cells [4]. In the all mentioned fuel cells hydrogen has an important role in anode and these fuel cells are known as $\mathrm{H}_{2}$ fuels. While, in non- $\mathrm{H}_{2}$ fuel cells including Direct-ethanol fuel cells (DEFCs), Direct-methanol fuel cells (DMFCs), Reformed Methanol Fuel Cell (RMFC) and Direct-formic acid fuel cells (DFAFCs) other chemical compounds such as ethanol, methanol and formic acid act as electron donor in anode $[11,12]$. Fuel cells offer many advantages such as high efficiency, high energy density, quiet operation, and environmental friendliness [4]. Following parts aim to describe some of fuel cell types in more details.

\section{Alkaline fuel cell (AFC)}

AFCs are the first and the only type of cells to have reached successful routine applications mainly in space explorations such as space shuttle mission in the United States [2]. As illustrated in Figure 2, AFCs use liquid electrolyte solution of potassium hydroxide $(\mathrm{KOH})$ due to its high alkaline hydroxide conductibility [9]. The AFCs generate electricity from hydrogen in which hydroxyl ion $\left(\mathrm{OH}^{-}\right)$ from potassium hydroxide migrates from the cathode to the anode. At the anode, hydrogen gas reacts with the $\mathrm{OH}^{-}$ions to produce water and release electrons $[11,12]$. The overall reactions are given as below:

$$
\begin{array}{lc}
\text { Anode } & 2 \mathrm{H}_{2}+4 \mathrm{OH}^{-} \rightarrow 4 \mathrm{H}_{2} \mathrm{O}+4 \mathrm{e}^{-} \\
\text {Cathode } & \mathrm{O}_{2}+2 \mathrm{H}_{2} \mathrm{O}+4 \mathrm{e}^{-} \rightarrow 4 \mathrm{OH}^{-}
\end{array}
$$

Overall cell reaction:

$$
2 \mathrm{H}_{2}+\mathrm{O}_{2} \rightarrow 2 \mathrm{H}_{2} \mathrm{O}+\text { electrical energy }+ \text { heat }
$$

AFCs offer some advantages over other fuel cells, mainly relatively low operating temperature. High-temperature AFCs operate at temperatures between $100^{\circ} \mathrm{C}$ and $250^{\circ} \mathrm{C}$. However, newer AFC designs operate at much lower temperatures ranging from $23^{\circ} \mathrm{C}$ to $70^{\circ} \mathrm{C}$. Another advantage is that higher reaction kinetics at the electrodes results in higher cell voltages. This high electrical efficiency permits the use of lower quantities of a noble expensive metal catalyst like platinum [9]. AFCs produce potable water in addition to electricity. Therefore, they have been a logical choice for spacecrafts. Most of the AFCs have been designed for transport applications [13]. One of the major drawbacks of the AFCs is that alkaline cells need very pure fuels [9]. It is related to the use of the liquid electrolyte $[14,15]$. The $\mathrm{KOH}$ solution is very sensitive to the presence of $\mathrm{CO}_{2}$. When air is used instead of oxygen, the hydroxyl ions may react with $\mathrm{CO}_{2}$ contained in the air and an unwanted chemical reaction forms a solid $\mathrm{K}_{2} \mathrm{CO}_{3}$ that interferes with the other chemical reactions inside the cell $[14,16,17]$. Another disadvantage is related to the amount of liquid electrolyte. If the liquid is higher or below the required level, it can lead to electrode flooding or electrode drying [9].

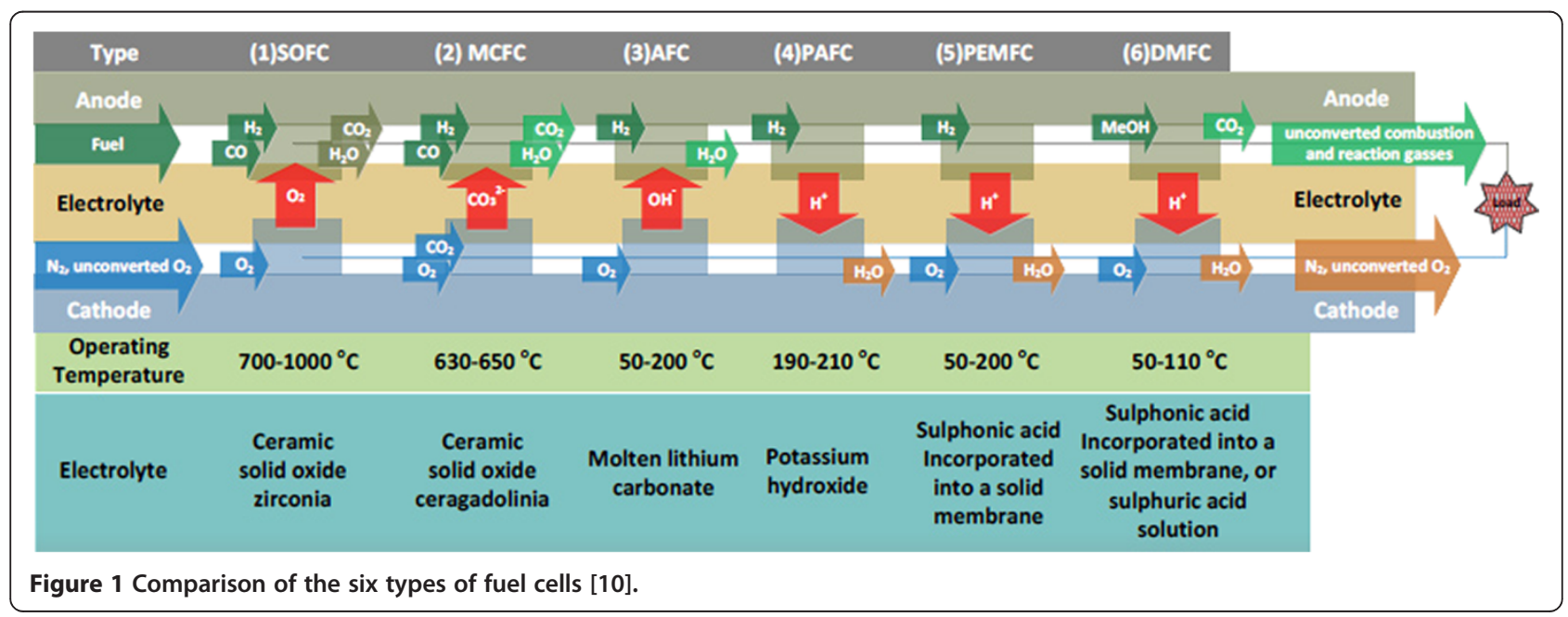




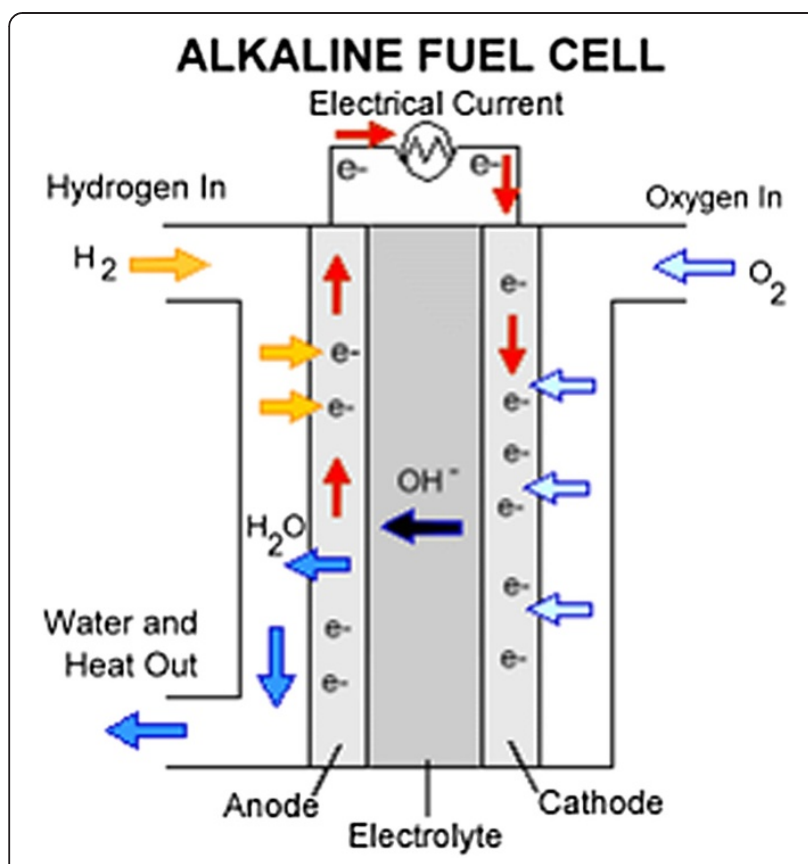

Figure 2 Schematic representation of an alkaline fuel cell (AFC) [2].

Molten carbonate fuel cell (MCFC)

As shown in Figure 3, MCFCs are high-temperature fuel cells that use an electrolyte composed of a molten carbonate salt mixture (salt of sodium or magnesium carbonate) suspended in a porous, chemically inert ceramic lithium aluminum oxide $\left(\mathrm{LiAlO}_{2}\right)$ matrix. In MCFCs the electrolytes are heated to $650^{\circ} \mathrm{C}$, and the salts melt and conduct

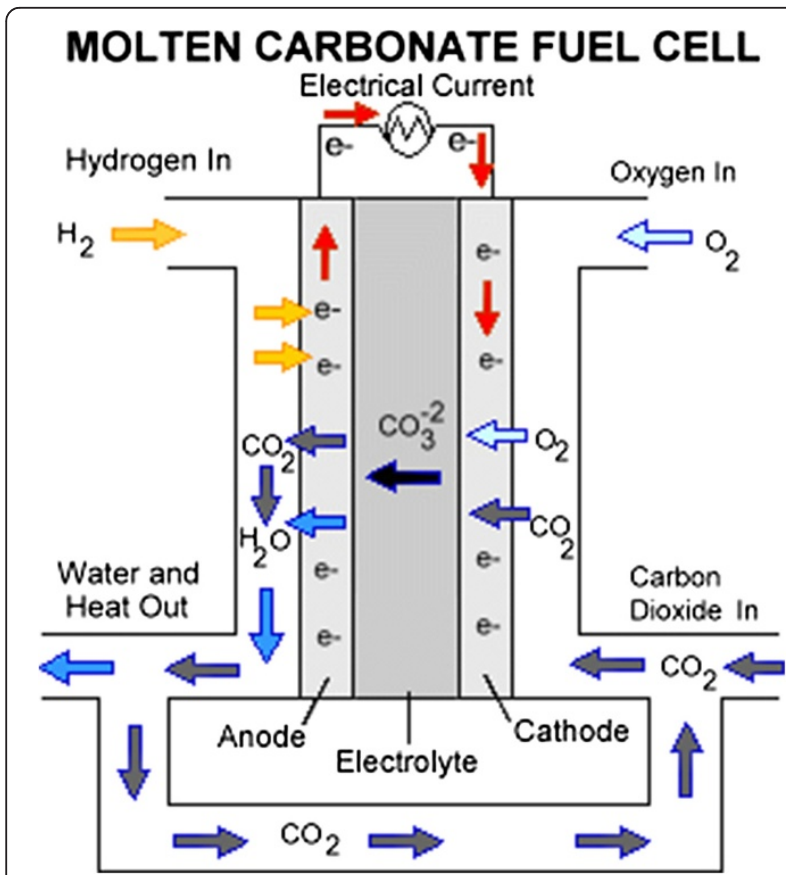

Figure 3 Schematic representation of a molten carbonate fuel cell (MCFC) [2]. carbonate ions $\left(\mathrm{CO}_{3}^{2-}\right)$ from the cathode to the anode [18]. At the anode, hydrogen oxidation reaction combines with carbonate ions producing water and carbon dioxide and releasing electrons to the external circuit. At the cathode, oxygen is reduced to carbonate ions by combining with carbon dioxide and electrons from the external circuit, therefore, electrochemical reactions are as below [2]:

$$
\begin{array}{ll}
\text { Anode } & \mathrm{H}_{2}+\mathrm{CO}_{3}{ }^{2-} \rightarrow \mathrm{H}_{2} \mathrm{O}+\mathrm{CO}_{2}+2 \mathrm{e}^{-} \\
\text {Cathode } & 1 / 2 \mathrm{O}_{2}+\mathrm{CO}_{2}+2 \mathrm{e}^{-} \rightarrow \mathrm{CO}_{3}{ }^{2-}
\end{array}
$$

Overall cell reaction:

$$
\mathrm{H}_{2}+1 / 2 \mathrm{O}_{2} \rightarrow \mathrm{H}_{2} \mathrm{O}+\text { electrical energy }+ \text { heat }
$$

The high operating temperature of these cells limits damage from the carbon monoxide poisoning of the cells and waste heat can also be recycled to make additional electricity $[19,20]$. The primary disadvantage of current MCFC technology is durability. High operating temperatures and the use of corrosive electrolytes accelerates component breakdown and cell life. Scientists are currently exploring corrosion-resistant materials for components as well as fuel cell designs that can increase cell life without decreasing their performance [2].

\section{Phosphoric acid fuel cell (PAFC)}

PAFCs are considered as the first generation of modern fuel cells. They are the most mature cell types and the first used commercially. Unlike the AFCs which were primarily developed for space applications, the PAFCs were targeted initially for terrestrial commercial applications with $\mathrm{CO}_{2}$ containing air as the oxidant gas and hydrocarbons (natural gas in particular) as the primary fuel for power generation. As the name implies, the PAFCs use the phosphoric acid $\left(\mathrm{H}_{3} \mathrm{PO}_{4}\right)$ in highly concentrated form (>95\%) as its electrolyte and porous carbon electrodes containing platinum catalyst which significantly increases the cost of the cell $[2,21]$. Internal parts of PAFCs must be able to withstand the corrosive acids [22]. The electrolyte is often immobilized in a porous silicon carbid $(\mathrm{SiC})$ matrix by capillary action. Pure hydrogen or hydrogen-rich gases can be used as fuel and air is almost invariably used as oxidant. PAFCs normally operate at temperatures between $170^{\circ} \mathrm{C}$ to $210^{\circ} \mathrm{C}$. Because the acid electrolyte is tolerant to the presence of $\mathrm{CO}_{2}$ in the reactant gas streams, hydrogen produced by steam reforming of organic fuels, such as hydrocarbons (typically natural gas or methane) and alcohols (mainly methanol or ethanol) are often used as the anodic reactant (Figure 4) [2]. These cells are more efficient (80\%) when used for the co-generation of electricity and heat as compared to generating electricity alone (40-50\%) $[22,23]$. Moreover, PAFCs can tolerate a carbon monoxide concentration of about $1.5 \%$, which broadens the choice of their use [22]. 


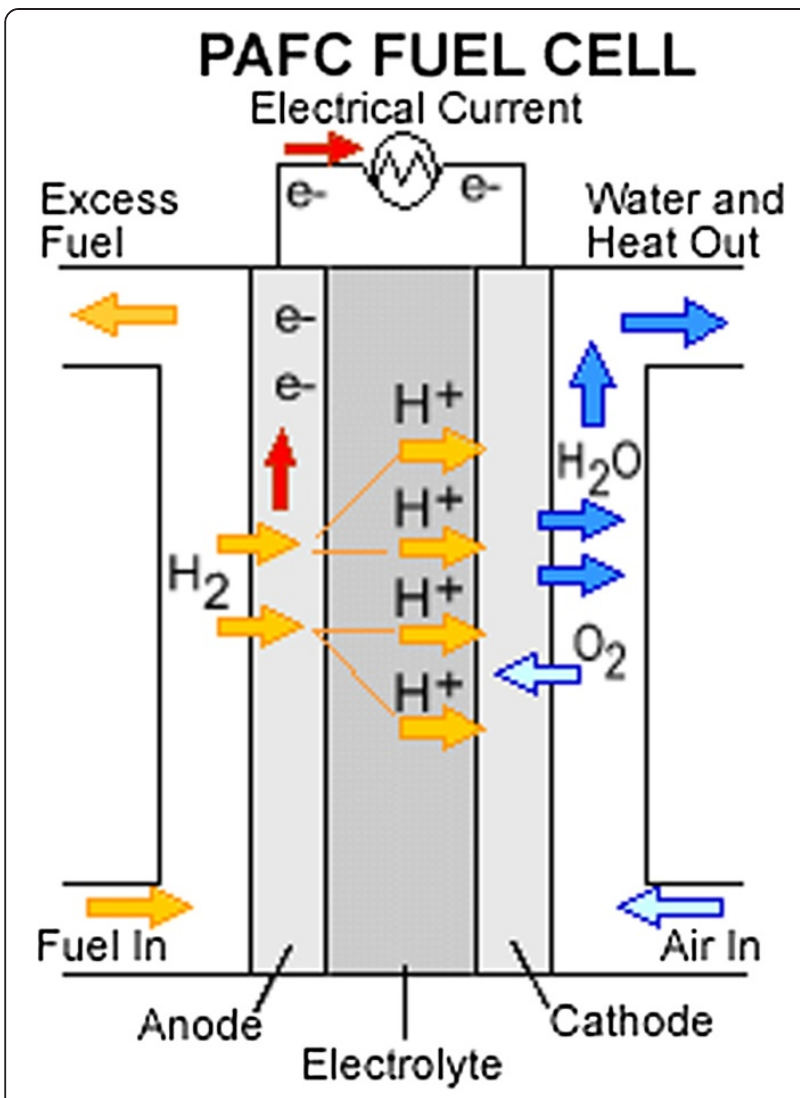

Figure 4 Schematic representation of a phosphoric acid fuel cell (PAFC) [2].

\section{Proton exchange membrane fuel cell (PEMFC)}

Proton exchange membrane fuel cells (PEMFC) also known as Polymer electrolyte membrane (PEM) fuel cells are consisted of a proton conducting cast in solid polymer form. Electrodes are porous carbon containing a platinum or ruthenium catalyst. PEMFCs deliver high-power density and offer the advantages of low weight and volume, no free corrosive liquid and hence longer cell lifetime compared to other fuel cells [2]. Schematic representation of a PEMFC is shown in Figure 5. There are two types of proton exchange membrane fuel cells, namely: hydrogen fuel cells and direct methanol fuel cells (DMFC), both of which utilize proton exchange membrane to transfer protons [13]. In hydrogen fuel cells at the anode, hydrogen is oxidized to liberate two electrons and two protons [24]. The protons are conducted from the catalyst layer through the proton exchange membrane and the electrons travel through the electronic circuits. At the cathode, oxygen is reduced to water. The overall reactions are given by:

$$
\begin{array}{lc}
\text { Anode } & \mathrm{H}_{2} \rightarrow 2 \mathrm{H}^{+}+2 \mathrm{e}^{-} \\
\text {Cathode } & 1 / 2 \mathrm{O}_{2}+2 \mathrm{H}^{+}+2 \mathrm{e}^{-} \rightarrow \mathrm{H}_{2} \mathrm{O} \\
\text { Overall } & \mathrm{H}_{2}+1 / 2 \mathrm{O}_{2} \rightarrow \mathrm{H}_{2} \mathrm{O}
\end{array}
$$

In direct methanol fuel cells, the solution of methanol and water is fed to the anode where it is internally reformed by the catalyst and oxidized to liberate electrons and protons. The cathode reaction for DMFC is similar to a hydrogen fuel cell [25]. The overall reactions for this type of cells are given as below:

$$
\begin{array}{ll}
\text { Anode } & \mathrm{CH}_{3} \mathrm{OH}+\mathrm{H}_{2} \mathrm{O} \rightarrow \mathrm{CO}_{2}+6 \mathrm{H}^{+}+6 \mathrm{e}^{-} \\
\text {Cathode } & 3 / 2 \mathrm{O}_{2}+6 \mathrm{H}+6 \mathrm{e}^{-} \rightarrow 3 \mathrm{H}_{2} \mathrm{O} \\
\text { Overall } & \mathrm{CH}_{3} \mathrm{OH}+3 / 2 \mathrm{O}_{2} \rightarrow \mathrm{CO}_{2}+2 \mathrm{H}_{2} \mathrm{O}
\end{array}
$$

Compared to hydrogen fuel cells, DMFC is further advantageous for its ease of fuel delivery, storage, operation at low temperature and lack of humidification requirements, as well as its reduced design complexity and high power density [26]. Despite these advantages limited operating temperatures, susceptibility to osmotic swelling, methanol crossover and high costs are among the factors hindering the commercialization of DMFC [27].

\section{Solid oxide fuel cell (SOFC)}

Solid oxide fuel cells (SOFCs) are best suited for large-scale stationary power generators that are able to provide electricity for factories and towns $[11,28]$. SOFCs, as shown in Figure 6, mainly use a hard ceramic compound of metal, such as calcium oxide or zirconium oxide as the electrolyte [29]. Hydrogen and carbon monoxide can be used as the reactive fuels in SOFCs [30]. SOFCs are expected to be around $50 \%-60 \%$ efficient at converting fuel to electricity. In applications designed to capture and utilize the system's waste heat (co-generation), overall fuel use efficiencies could be up to $80-85 \%$. Solid oxide fuel cells operate at very high temperatures of $1000^{\circ} \mathrm{C}$. The oxygen is supplied, usually from air at the cathode. At these high temperatures, oxygen ions (with a negative charge) migrate through the crystal lattice. When a fuel gas containing hydrogen passes over the anode, a flow of negatively charged oxygen ions move across the electrolyte to oxidize the fuel [31]. When hydrogen is used as the fuel the reactions $\mathrm{c}$ [30]:

$$
\begin{aligned}
& \text { Anode } \mathrm{H}_{2}+\mathrm{O}^{2-} \rightarrow \mathrm{H}_{2} \mathrm{O}+2 \mathrm{e}^{-} \\
& \mathrm{H}_{2}+{ }^{1 / 2} \mathrm{O}_{2} \rightarrow \mathrm{H}_{2} \mathrm{O}+\text { electrical energy }+ \text { heat }
\end{aligned}
$$

And when carbon monoxide is the fuel the reactions are:

$$
\begin{aligned}
& \text { Anode } \quad \mathrm{CO}+\mathrm{O}^{2-} \rightarrow \mathrm{CO}_{2}+2 \mathrm{e}^{-} \\
& \text {Cathode } 1 / 2 \mathrm{O}_{2}+2 \mathrm{e}^{-} \rightarrow \mathrm{O}^{2-} \\
& \text { Overall } \mathrm{CO}+1 / 2 \mathrm{O}_{2} \rightarrow \mathrm{CO}_{2}
\end{aligned}
$$

High-temperature operation removes the need for precious-metal catalyst, thereby reducing the cost. However, the high temperature limits applications of SOFCs units and they tend to be rather large, while solid electrolytes cannot leak, they can crack [32]. 


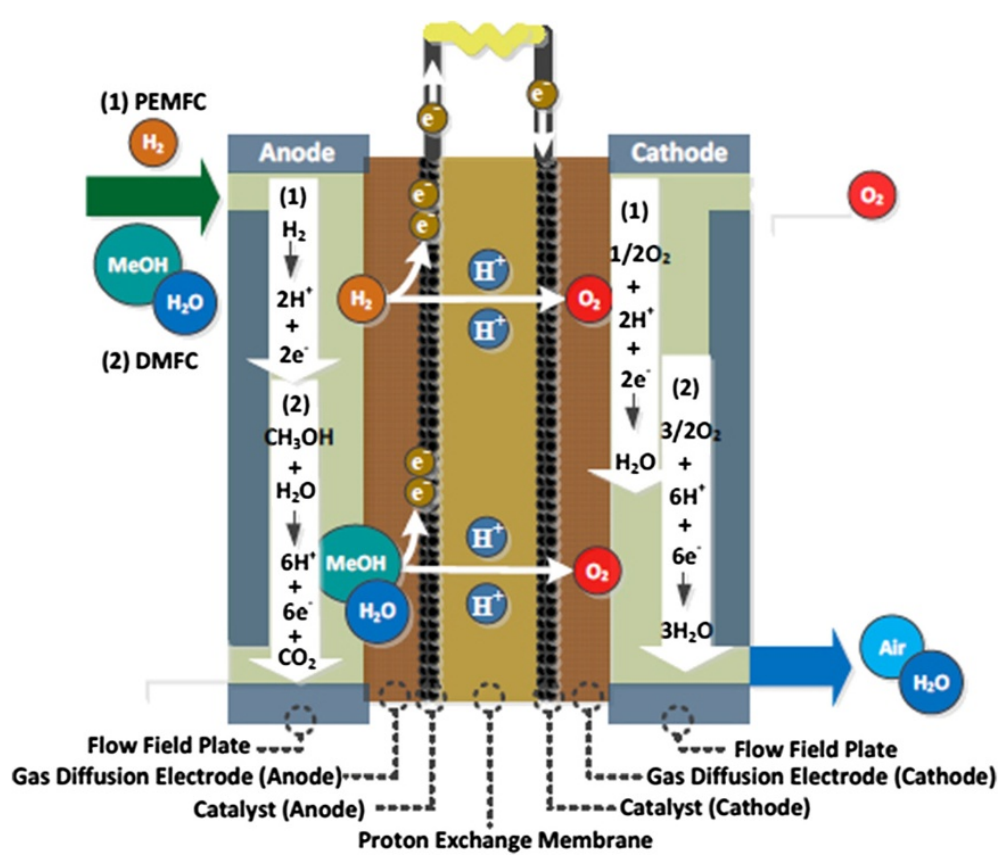

Figure 5 Schematic representation of a proton exchange membrane fuel cell (PEMFC) [4].

\section{Biofuel cell}

Microorganisms are able to convert enormous amounts of energy from an incomparable range of chemical substrates [33]. Biofuel cells are a subset of fuel cells that employ biocatalysts such as a microbe, enzyme or even

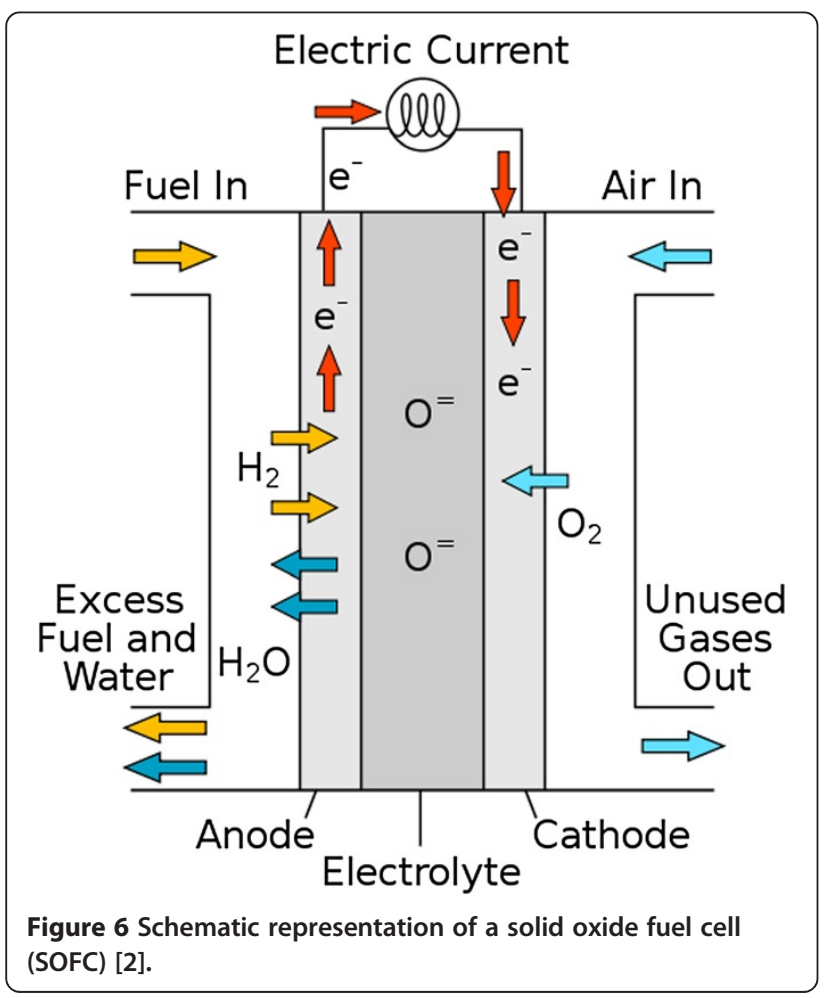

organelle interacting with an electrode surface [34,35]. The main types of biofuel cells are defined by the type of biocatalyst. Microbial fuel cells employ living cells to catalyze the oxidation of the fuel, whereas enzymatic fuel cells use enzymes for this purpose [36]. These types of catalysts offer great benefits in catalytic activity, specificity and cost. However, development and full evaluation of these dynamic and often sensitive bioelectrochemical systems require a diverse range of expertise [33]. Biofuel cells like other ones require porous anode and cathode structures that support fuel transport to the catalyst reaction sites [36]. Either a polymer electrolyte membrane or a salt bridge can separate the electrodes. The two main application areas that are being considered for enzymatic biofuel cells are in vivo, implantable power supplies for sensors and pacemakers and ex-vivo power supplies for small portable power devices (wireless sensor networks, portable electronics, etc.) [33].

\section{Enzymatic fuel cell (EFC)}

Enzymatic fuel cells (EFCs) which replace expensive metal catalysts with cheap enzymes are still in an early stage of their development [33]. A conventional EFC is shown in Figure 7. Enzymes have the advantage of specificity which can eliminate the use of a membrane separator. EFCs typically possess orders of magnitude higher power densities (although still lower than conventional fuel cells), but have limited lifetime (typically 7-10 days) due to the fragile nature of the enzyme and have low efficiency as only a single type of enzyme is employed and can only partially 


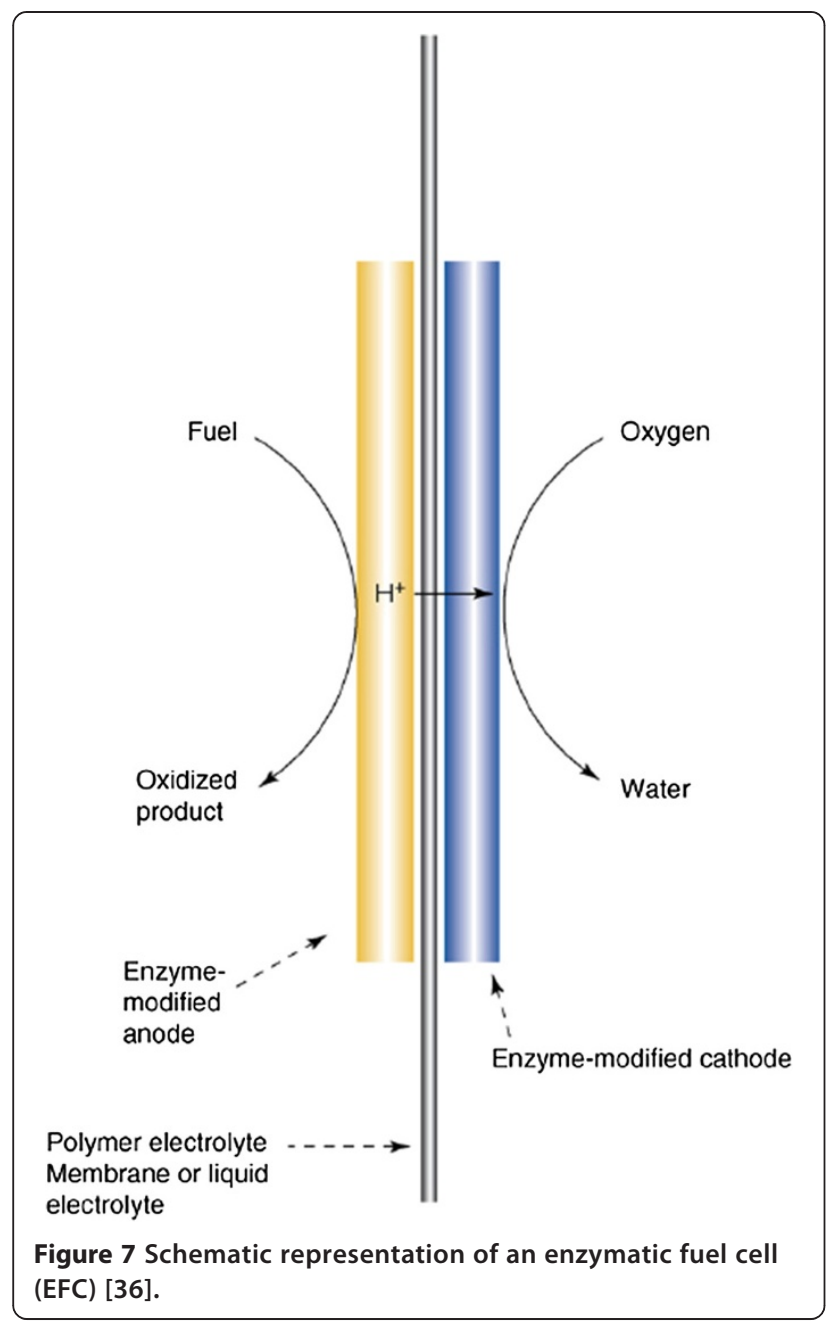

oxidize the fuel $[37,38]$. This is in contrast to living cells that multistep enzymatic cycles (i.e. Kreb's cycle) and pathways (i.e. glycolysis) can completely oxidize biofuels (e.g. ethanol, lactate and glucose) to carbon dioxide and water [36]. There are a number of strategies for solving these problems. Firstly, in terms of maximizing power density biofuel cell, anodes should poss multidimensional and multidirectional pore structures [39]. They should be able to optimize the need for surface area. Secondly, the successful immobilization of multienzyme systems that can completely oxidize the fuel to carbon dioxide is needed $[40,41]$. Finally, the anode must support efficient charge transfer mechanisms whether it is direct or mediated and balance electron transfer with proton transfer [36]. Several enzymes such as glucose oxidase, alcohol dehydrogenase, formate dehydrogenase, lactic dehydrogenase, glucose dehydrogenase and formaldehyde dehydrogenase were successfully immobilized and used in EFCs to date [42].

\section{Microbial fuel cell (MFC)}

Microbial fuel cells (MFCs) employ living cells [36]. MFCs are obtained when catalyst layer used into classical fuel cells (polymer electrolyte fuel cell) is replaced with electrogenic bacteria [43]. Figure 8 represents a schematic of MFCs. As clearly observed in this figure, the substances (organics represented as chemical oxygen demand) are oxidized to $\mathrm{CO}_{2}$ by microorganisms, which transfer the gained electrons to the anode. At the cathode, the electrons are used to reduce oxygen abiotically or biotically to produce water. To maintain electro neutrality within the system, positive charges have to migrate from the anode to the cathode through an ion-permeable separator (for example a cation exchange membrane) [44]. The current advantages of MFCs are that they have long lifetimes (up to five years) and are capable of completely oxidizing simple sugars to carbon dioxide [45-47]. However, they deliver low power densities owing to slow transport across cellular membranes [48]. MFCs are a promising technology for efficient wastewater treatment and generating energy as direct electricity for onsite remote application [43].

\section{Polymer membranes for fuel cells}

Interest in some kinds of fuel cell technologies dropped owing to economic factors, material problems, and certain inadequacies in the operation of electrochemical devices [49]. One of the main drawbacks of the fuel cells is related to the use of the liquid electrolyte. Using a polymer membrane as an electrolyte can solve some limiting requirements of fuel cells. For instance the essentially need for using pure fuels in AFCs have been overcome by using a polymer membrane as an electrolyte [14,15]. Fuel cell membranes must meet several desired properties such as high proton conductivity, low electronic conductivity,

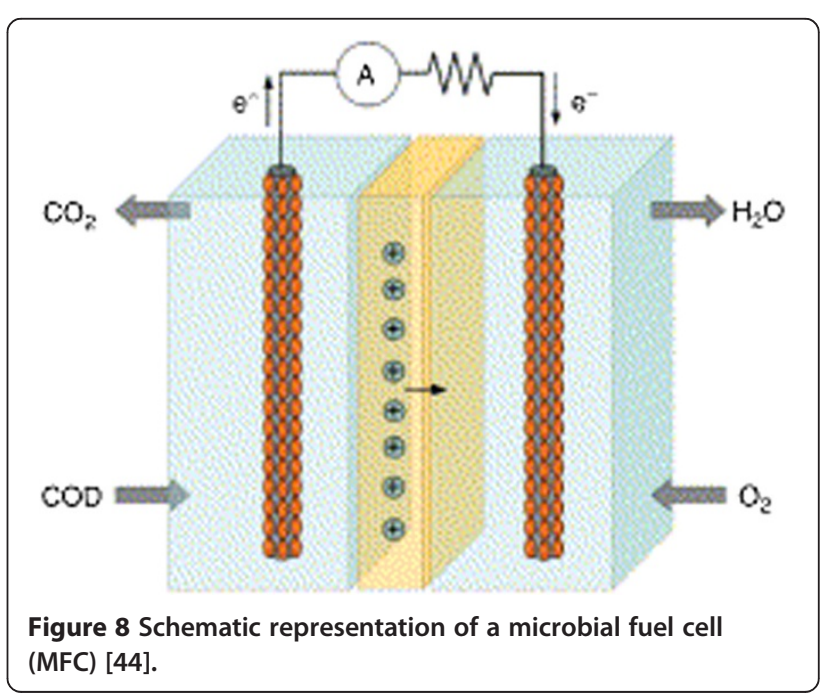


impermeability to fuel gas or liquid, good mechanical toughness in both the dry and hydrated states, and high oxidative and hydrolytic stability in the actual fuel cell environment [4]. These properties are related to properties such as ion exchange capacity, morphology and water uptake that must be assessed as well when characterizing potential of a new fuel cell membrane [9].

\section{Recent development of proton exchange membranes}

The first polymer electrolyte membrane (PEM) used in a fuel cell system was sulfonated polystyrene membrane. It was developed by General Electric for NASA in the early 1960s, as on-board power source in the Apollo flight space mission [50]. However, this material was found to have several major weaknesses such as lack of stability and limited power density [51]. Currently, most commercially available membranes for fuel cells are based on perfluorosulfonic acid (PFSA) polymer membranes (e.g., Nafion, Flemion and Acipex) [4].

Commercial PEMs have many advantages such as high proton conductivities at moderate operating temperatures and wide range of relative humidities as well as good physical and chemical stabilities. There are, however, several drawbacks which have limited PFSA's application including its high cost, high methanol permeability and environmental incompatibility with other materials [27]. To overcome these obstacles, extensive efforts have been made to develop alternative low-cost membranes as potential PEMs. Most current development strategies have used modified PFSA polymers (partially fluorinated), acid functionalized aromatic hydrocarbon-based polymers or a number of sulfonated aromatic polymers and composite membranes. Composite membrane incorporates inorganic materials, acids or other polymers into a polymer matrix [4]. The modification efforts of PFSA membrane have been focused on minimizing the methanol crossover which is particularly serious in the DMFC system. Aromatic fluorinated polymers have been emphasized not only due to the high cost of PFSA but also other fuel cell associated characteristics such as high mechanical and thermal stability, chemicals, acids and bases, good resistance to oxidation and very interesting surface properties [52]. Most alternative polymer membranes are summarized in Table 1.

\section{Recent development of anion exchange membranes}

In the solid AFC, the Anion Exchange membrane (AEM) is one of the core components. In order to improve fuel cell performance, the membrane must possess certain properties. The role of the membrane is carrier for ion (ionic conductor) and a barrier for gas and electrons (electronic insulator). The most important advantage of using a solid anion exchange membrane instead of a liquid electrolyte in AFCs is to eliminate the negative effects of
$\mathrm{CO}_{2}$. The conducting species is now in a fixed solid polymer, therefore, there will be some carbonates due to the reaction of the $\mathrm{OH}^{-}$with $\mathrm{CO}_{2}$ but because there are no mobile cations $\left(\mathrm{K}^{+}\right)$, solid crystals of metal carbonate will not be formed to block the gas diffusion electrodes. The main idea behind employing an anion exchange membrane (AEM) in an AFC is to improve the AFC's efficiency and life (slow down performance degradation with time) [9]. Important challenges for the preparation of an efficient AEM are ionic conductivity and mechanical stability. Table 2 offers an overview of the various polymeric materials that are or can be used in AFCs.

\section{Chitosan biopolymer for fuel cell applications}

Chitosan, as a natural polymer, is one of the promising membrane materials and has been studied widely. As shown in Figure 9, it is the N-deacetylated derivative of chitin which is naturally abundant polysaccharide and the supporting material of crustaceans, insects, etc. Chitin is easily obtained from crabs or shrimp shells and fungal mycelia. Chitosan is inert, hydrophilic and is insoluble in water, alkali and organic solvents. Its solubility in dilute organic acids allows for gel formation in various configurations. Chitosan has been studied as membrane material for ultrafiltration, reverse osmosis, pervarporation, and lithium batteries [8]. The removal of proteins in chitin by heat treatment causes its deacetylation simultaneously. Free amine and hydroxyl functional groups on the chitosan's backbone enable various chemical modification of chitosan to tailor it for specific applications such as polymer electrolyte membrane for the separation of metal ions, amino acids and protein by adsorption, ultrafiltration, electro-ultrafiltration, fuel cell application and pervaporation [83]. Utilization of a chitosan biopolymer for fuel cell technologies is novel and challenging where biological products are usually considered as waste, non-hazardous, low cost and environmentally benign [84]. Chitosan-based membranes are easily formed and have high hydrophilicity, good chemical and thermal stability [4]. Chitosan, as a natural abundant biopolymer is receiving great interest as materials for both membrane electrolyte and electrode in various fuel cells such as polymer electrolyte-based fuel cell including alkaline polymer electrolyte fuel cells, direct methanol fuel cells and biofuel cells [5].

\section{Current advances in application of chitosan biopolymer as electrolyte membrane in fuel cells}

Membrane is the core component of PEMFCs. Considering that polymer membrane electrolyte is the most expensive component of a polymer electrolyte-based fuel cell, the use of low-cost chitosan-based membrane might bring down the cost of a fuel cell [5]. Chitosan-based membrane electrolyte is being studied as alternative candidate for polymer 
Table 1 Alternative polymer membranes used in fuel cell

\begin{tabular}{|c|c|c|c|}
\hline Alternative polymer membranes & References & Alternative polymer membranes & References \\
\hline $\begin{array}{l}\text { The depositing of thin plasma polymerized barrier } \\
\text { films on Nafion }{ }^{\circledR} \text { membrane }\end{array}$ & [53] & sulfonated poly(ether ether ketone) (SPEEK) & [54] \\
\hline Nafion ${ }^{\circledR} /$ silicon oxide & [55] & Poly methyl methacrylate (MAA) & [4] \\
\hline Nafion ${ }^{\circledR} / \mathrm{Pd}$ & [56] & PVA & [4] \\
\hline Nafion/Pd-Ag alloy & [57] & Poly vinyl sulfonic acid (PVS) & [4] \\
\hline plasma-etched membrane, & {$[58]$} & Sulfonated poly(arylene ether sulfone) (BPSH) & [59] \\
\hline \multicolumn{4}{|l|}{ Pd-sputtered membrane, } \\
\hline \multicolumn{4}{|l|}{ plasma etched and Pd-sputtered membrane } \\
\hline $\begin{array}{l}\text { Nafion }{ }^{\circledR} \text { with montmorillonite (MMT) and MMT containing } \\
\text { dodecylamine (m-MMT) membranes }\end{array}$ & {$[60]$} & Poly p-Styrene carboxylic (SCA) & [4] \\
\hline Nafion ${ }^{\circledR} /$ polypyrrole & {$[61]$} & Dimethylaminoethyl methacrylate (DMAEMA) & [4] \\
\hline Nafion ${ }^{\circledR} /$ polyvinyl alcohol (PVA) & [62] & Polyphosphazene (PPh) & {$[63,64]$} \\
\hline $\begin{array}{l}\text { Nafion }{ }^{\circledR} / \text { phosphotungstic acid-impregnated silicon } \\
\text { dioxide (SiO2/PWA), }\end{array}$ & {$[65,66]$} & Polybenzimidazole (PBI) & {$[67,68]$} \\
\hline \multicolumn{4}{|l|}{ Nafion ${ }^{\circledR} / \mathrm{SiO} 2$, } \\
\hline \multicolumn{4}{|l|}{ Nafion ${ }^{\circledR}$ /alumina (b-Al2O3) } \\
\hline Nafion ${ }^{\circledR} /$ zirconium phosphate (ZrP) & [69] & Sulfonated poly(phthalazinone ether ketone) (SPPEK) & [70] \\
\hline$\alpha, \beta, \beta$-trifluorostyrene (TFS) & [71] & PVA/PWA & [72] \\
\hline TFS/styrene & [73] & PVA/PWA and silica & [74] \\
\hline TFS/vinyl fluoro monomers & [75] & SPEEK/Synthetic non-spherical silicates & [76] \\
\hline polytetrafluoroethylene (PTFE) & [77] & SPEEK/Zirconia (ZrO2) & [78] \\
\hline Poly (ethylene glycol) (PEG) & {$[4]$} & PVA/Polystyrene sulfonic acid (PSSA) & [79] \\
\hline Poly (ethylene-alt tetrafluoroethylene) (ETFE) & [77] & PBI/Sulfonated polysulfone (SPf) & [80] \\
\hline Sulfonated polyimides (SPI) & [81] & Polysulfone (PSf)/PEG & [82] \\
\hline
\end{tabular}

electrolyte membrane application to possibly produce economical fuel cells [5]. To achieve high efficiency, membrane must possess as mentioned before some desirable properties [83]. Modification of chitosan such as sulfonation, phosphorylation, quaternization, chemical cross-linking makes it cost-effective polymer electrolyte membrane with low methanol permeability and suitable ion conductivity especially at high temperature [3].

\section{Chitosan membrane for AFCs}

Recently, derivatives of chitosan were created to serve as novel polyelectrolytes for AFCs. N-[(2-Hydroxy-3trimethylammonium) propyl] chitosan chloride was synthesized, followed by cross-linking with glutaraldehyde [85]. Crosslinked quaternized-PVA has a low mechanical strength; therefore, Xiong et al. blended this polymer with chitosan to improve their performance [86]. The obtained composite membranes have more compact structure and good mechanical strength. Wan et al. examined the ionic conductivity of different chitosan membranes, such as pure chitosan membranes with different degree of deacetylation and molecular weight, di-o-butyrylchitosan, epichlorohydrin or glutaraldehyde cross-linked chitosan and proposed that they are suitable for use in alkaline fuel cells [87-90].
Polystyrene (PS) was introduced to form an interpenetrating network with quaternized chitosan. Polystyrene is more hydrophobic than quaternized chitosan and has good mechanical strength. It was found that introduction of PS improves tensile strength, and yet reduces elongation. The addition of PS enabled the quaternary ammonia-based membranes to have a higher tolerance to bases. However, the membranes with a higher PS exhibit lower ionic conductivity due to the PS are a nonionic conductor [91].

\section{Chitosan membrane for DMFC}

For application in a DMFC, polymer electrolyte membrane needs to have a low methanol crossover. The commonly used Nafion membrane has relatively high methanol permeability. Chitosan has been employed as a promising polymeric matrix for DMFC application considering its low cost, desirable alcohol barrier property and proton conductivity as well as adequate thermal stability after cross-linking $[26,92]$. In its dry state, chitosan has a very low electrical conductivity. The addition of salts leads to the formation of complex between salts and chitosan matrix, and also enhancement of its amorphous nature [93]. Plasticization is able to increase the amorphous content and thus improves the conductivity of a solid polymer electrolyte 
Table 2 Anion exchange membranes used in AFCs [9]

\begin{tabular}{ll}
\hline Anion exchange membranes & \\
\hline PVA/TiO2 cross-linked & Tetra alkyl ammonium Functionalized polyethylene \\
PVA/KOH & PVA/poly(1,3-diethyl-1 vinyl imidazolium bromide) \\
PVA/PEO/KOH & Cationic poly (phenylene) \\
PVA/PECH/KOH & Quaternized/cross-linked PVA-chitosan \\
PVA/TEAC/KOH & PSU/trimethyl ammonium \\
PVA/PAA & Carboxylic Nafion 117 \\
PVA-poly (acrylonitrile-co -2-dimethylaminoethylmethacrylate) & Sulfonic Nafion \\
PBI/ $K O H$ & Chitosan \\
PEO-[Si(OCH$)_{3} 2(+)$ & N-[(2-hydroxy-3trimethylammonium)propyl] chitosan \\
PVA-[Si(OCH$)_{3} 2(+)$ & Poly(methyl methacrylate-co-butyl-acrylate-co-vinyl benzyl \\
Alkoxysilane/acrylate or epoxy alkoxysilane & Crosslinked ionic liquid \\
Tetra alkyl ammonium functionalized cyclooctene & Quaternary ammonia polysulfone \\
Poly(methyl methacrylate-co butyl-acrylate-co-vinyl benzyl & Polyarylene sulfonium membrane
\end{tabular}

[94]. Cross-linking is proposed to reduce crystallinity of chitosan membrane and simultaneously enhance the ionic transport [95]. Chitosan is hydrophilic and consequently has a high degree of swelling. An excessively high level of water uptake increases the fragility of the membrane and makes it less durable in fuel cells. To overcome the disadvantage of loss in mechanical strength in the wet state, chitosan is blended with tough polymers such as polyvinyl pyrrolidone (PVP) [96]. Mat, et al. fabricated a polymer electrolyte composite membrane that comprises of chitosan, PVA and calcium oxide $(\mathrm{CaO})$. These results indicate that chitosan-PVA$\mathrm{CaO}$ composite membranes have excellent methanol barrier properties which in turn make them feasible for DMFC applications [3].

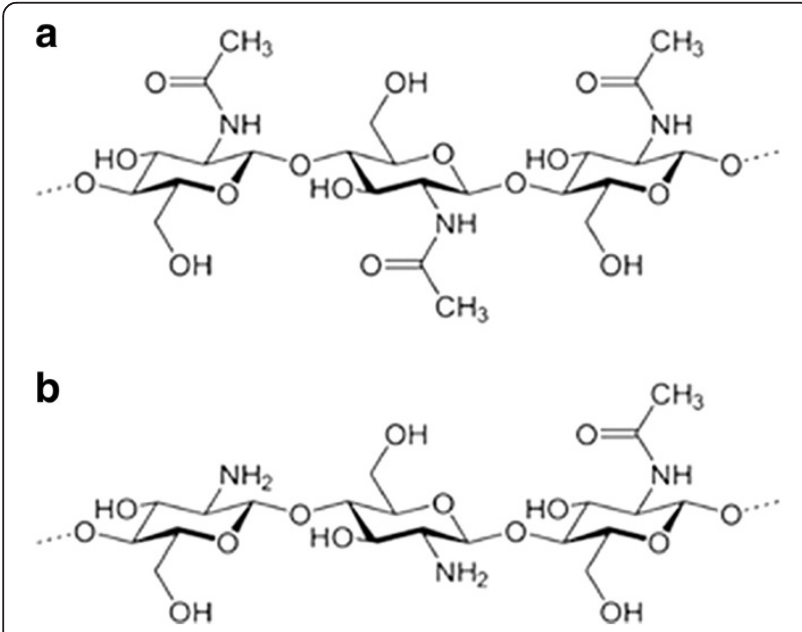

Figure 9 Chemical structure of chitin (a) chitosan (b) [8].

\section{Current advances in application of chitosan biopolymer as electrode in fuel cells}

An electrode in a polymer electrolyte-based fuel cell usually consists of supported or unsupported catalyst with or without binder loaded on an electrode substrate or a gas diffusion layer. Polymeric materials are often employed as binder to bond catalyst particles and also provide ionic conduction [5]. Nafion material is also used as electrode binder which facilitates ionic conduction that provides mechanical support for catalyst particles and enhances dispersion of catalyst particles in the catalyst layer. Nafion possesses many desirable properties as a polymer electrolyte, and yet it is very expensive and loses ionic conductivity if not sufficiently hydrated [5]. The chitosan binder exhibited better performance than a Nafion binder especially at elevated cell temperatures, ascribed to the hydrophilic nature and water retention characteristics of chitosan. In addition, the amount of required chitosan binder for making electrode is much less than that of Nafion binder [97]. Klotzbach et al. modified chitosan with butanal, hexanal, octanal or decanal aldehydes to prepare a biocompatible and biodegradable hydrophobic chitosan membrane that can replace Nafion for electrode coatings in both sensor and fuel cell applications [98,99]. Functionalization of carbon nanotube by chitosan introduces positively charged functional groups on the surface of carbon nanotube which serves as a medium to stabilize and anchor metal nanoparticles through electrostatic self-assembly and also provides proton path for methanol electrooxidation reactions [100]. Wang et al. reported that chitosan/tungstophosphoric acid modified $\mathrm{Pt} / \mathrm{C}$ catalyst demonstrated higher utilization efficiency as compared to pristine Pt/C catalyst [101]. 


\section{Chitosan for biofuel cells}

To develop a stable enzymatic biofuel cell, a matrix for enzyme immobilization is critical to retain the activity of enzyme in a long period [102]. Carboxyl and amine side groups of chitosan can serve as protein-binding ligands for enzyme immobilization [103-105]. Three-dimensional electrodes possessing multidimensional and multidirectional pore structures are possible solution to improve performance of a biofuel cell. Chitosan scaffold was used to fabricate enzymatic electrode that oxidizes glucose and produce electrical current more effectively than the same electrode made of a chitosan film [106]. The large pore size of chitosan scaffold enables it to support bacterial colonization of internal pores without increasing flow resistance [107]. It was reported that carbon nanotube/ chitosan nanocomposite bioelectrode enhanced the electricity generation of microbial fuel cells [108-110].

\section{Conclusion and perspective}

Fuel cells are often regarded as one of the advanced energy technologies for the future. However, commercialization of fuel cells is still a subject of the ongoing research. The development of PEMFC power system has been accelerated for vehicular and home-use applications. Pure hydrogen fuel appears likely to be the appropriate choice for vehicle applications. Although fuel cell technology has matured substantially over the past decades, special attention has to be given to composite techniques in developing electrolyte membrane since these techniques have proven their effectiveness. It is necessary to develop alternative membranes that have high ionic conductivity and have sufficient mechanical strength and chemical stability to be made as thin as possible. Recently, many efforts have been made in utilization of chitosan with improved properties for being used as a polymer electrolyte membrane and electrode in fuel cells. These chitosan based membranes generally do not offer significant advantages over traditional Nafion membrane as far as proton conductivity is concerned and as a result the corresponding power density of related fuel cells is also lower than Nafion-based ones. The intrinsic ionic conductivity of chitosan-based membrane, therefore, needs to be further improved for fuel cell application. The mechanical strength and shelf life of chitosan also need further enhancements which have not been given extensive attention to date. Efforts have been made to improve properties of chitosan membrane, including chemical modification such as sulfonation, phosphorylation, quaternization and formation of chitosan composite. These methods improve some properties of chitosan with or without sacrificing the others. Application of chitosan composite membranes has been proved to be effective approach in reducing their cost as well as improving their operating reliability.

\section{Competing interests}

The authors declare that they have no competing interests.

\section{Authors' contributions}

$\mathrm{HV}, \mathrm{HJM}, \mathrm{AB}$ and NA have contributed mainly to the study of application of chitosan in fuel cells, participated in the sequence alignment and drafted the manuscript. All authors read and approved the final manuscript.

\section{Author details}

${ }^{1}$ Department of Chemical Engineering, Sahand University of Technology, Tabriz, Iran. ${ }^{2}$ School of Chemical and Biomolecular Engineering, The University of Sydney, Sydney, Australia. ${ }^{3}$ Department of Engineering, Science and Research Branch, Islamic Azad University, Tabriz, Iran.

Received: 25 March 2013 Accepted: 7 August 2013

Published: 11 September 2013

\section{References}

1. Berenjian A, Chan N, Jafarizadeh Malmiri H: Volatile organic compounds removal methods: A review. Am J Biochem Biotechno/ 2012, 8:220-229.

2. Xianguo L: Principles of Fuel Cells. New York London: Taylor and Francis group; 1962.

3. Mat NC, Liong A: Chitosan-poly (vinyl alcohol) and calcium oxide composite membrane for direct methanol fuel cell applications. Eng Letters 2009, 17:301-304

4. Ye YS, Rick J, Hwang BJ: Water soluble polymers as proton exchange membranes for fuel cells. Polymers 2012, 4:913-963.

5. Ma J, Sahai Y: Chitosan biopolymer for fuel cell applications. Carbohydr Polym 2013, 92:955-975.

6. Varshney P, Gupta S: Natural polymer-based electrolytes for electrochemical devices: a review. Ionics 2011, 17:479-483.

7. Dash M, Chiellini F, Ottenbrite RM, Chiellini E: Chitosan-A versatile semi-synthetic polymer in biomedical applications. Prog Polym Sci 2011, 36:981-1014.

8. Jafarizadeh Malmiri H, Jahanian MA, Berenjian A: Potential applications of chitosan nanoparticles as novel support in enzyme immobilization. Am J Biochem Biotechnol 2012, 8:203-219.

9. Merle G, Wessling M, Nijmeijer K: Anion exchange membranes for alkaline fuel cells: A review. J Membr Sci 2011, 377:1-35.

10. Winter M, Brodd RJ: What are batteries, fuel cells, and supercapacitors? Chem Rev 2004, 104:4245-4270.

11. Cooper HW: A future in fuel cells. Chem Eng Progress 2007, 103:34-43.

12. Sopian K, Wan Daud RW: Challenges and future developments in proton exchange membrane fuel cells. Renew Energy 2006, 35:719-727.

13. Odeh $A O$, Osifo $P$, Noemagus $H$ : Chitosan: a low cost material for the production of membrane for use in PEMFC-A review. Energ Sources Part A 2013, 35:152-163.

14. Gülzow E, Schulze M: Long-term operation of AFC electrodes with $\mathrm{CO} 2$ containing gases. J Power Sources 2004, 127:243-251.

15. Gouérec P, Poletto L, Denizot J, Sanchez-Cortezon E, Miners JH: The evolution of the performance of alkaline fuel cells with circulating electrolyte. J Power Sources 2004, 129:193-204.

16. Schulze M, Gülzow E: Degradation of nickel anodes in alkaline fuel cells. J Power Sources 2004, 127:252-263.

17. Chakrabarty B, Ghoshal AK, Purkait MK: SEM analysis and gas permeability test to characterize polysulfone membrane prepared with polyethylene glycol as additive. $J$ Coll Interface Sci 2008, 320:245-253.

18. Bischoff $\mathrm{M}$ : A high temperature fuel cell on the edge to commercialization. J Power Sources 2006, 160:842-845.

19. Amorelli A, Wilkinson MB, Bedont P, Capobianco P, Marcenaro B, Parodi F, Torazza A: An experimental investigation into the use of molten carbonate fuel cells to capture $\mathrm{CO}_{2}$ from gas turbine exhaust gases. Energy 2004, 29:1279-1284

20. Kim YJ, Chang IG, Lee TW, Chung MK: Effects of relative gas flow direction in the anode and cathode on the performance characteristics of a molten carbonate fuel cell. J Membr Sci 2010, 89:1019-1028.

21. Cheddie DF, Munroe NDH: A two-phase model of an intermediate temperature PEM fuel cell. Int J Hydrogen Energy 2007, 32:832-841.

22. Sammes N, Bove R, Stahl K: Phosphoric acid fuel cell: Fundamentals and applications. Curr Opin Solid State Mater Sci 2004, 8:372-378.

23. Acres GJK: Recent advances in fuel cells technology and its applications. J Power Sources 2001, 100:60-66. 
24. Hoogers G: Fuel cell technology handbook. In Edited by Hoogers G. Boca Raton: FL: CRC Press; 2003:8-39.

25. Kreuer KD: On the development of proton conducting polymer membranes for hydrogen and methanol fuel cells. J Membr Sci 2001 185:29-39.

26. Ramirez-Salgado J: Study of basic biopolymers as proton membrane for fuel cell systems. Electrochim Acta 2007, 52:3766-3778.

27. Othman MHD, Ismail AF, Mustafa A: Recent development of polyme electrolyte membranes for direct methanol fuel cell application - A review. Malaysian Polym J 2010, 5:1-36.

28. Matelli JA, Bazzo E: A methodology for thermodynamic simulation of high temperature internal reforming fuel cell systems. J Power Sources 2005, 142:160-168.

29. Song SJ, Moon JH, Lee TH, Dorris SE, Balachandran U: Thickness dependence of hydrogen permeability for Ni-BaCe0.8Y0.2O3-ס. Solid State Ion 2008, 179:1854-1857.

30. Bagotsky VS: Fuel cells: problems and solutions. In Edited by Bagotsky VS Hobken, New Jersy: John Wiley \& Sons Inc; 2009:45-70

31. Xie $Y$, Xue $X$ : Transient modeling of anode-supported solid oxide fuel cells. Int J Hydrogen Energy 2009, 34:6882-6891.

32. Offer GJ, Brandon NP: The effect of current density and temperature on the degradation of nickel cermet electrodes by carbon monoxide in solid oxide fuel cells. Chem Eng Sci 2009, 64:2291-2300.

33. Moehlenbrock MJ, Arechederra RL, Sjoholm KH, Minteer SD: Analytical techniques for characterizing enzymatic biofuel cells. Anal chem 2009, 81:9538-9545.

34. Arechederra RL, Minteer SD: Organelle-based biofuel cells: Immobilized mitochondria at carbon paper electrodes. Electrochim Acta 2008, 53:6698-6703.

35. Palmore GTR: Bioelectric power generation. Trends Biotechnol 2004, 22:99-100.

36. Minteer SD, Liaw BY, Cooney MJ: Enzyme-based biofuel cells. Curr Opin Biotechnol 2007, 18:228-234.

37. Barton SC, Gallaway J, Atanassov P: Enzymatic biofuel cells for implantable and microscale devices. Chem Rev 2004, 104:4867-4886.

38. Kim J, Jia H, Wang P: Challenges in biocatalysis for enzymebased biofuel cells. Biotechnol Adv 2006, 24:296-308.

39. Katz E, Lioubashevski O, Willner l: Magnetic field effects on bioelectrocatalytic reactions of surface-confined enzyme systems: enhanced performance of biofuel cells. J Am Chem Soc 2005, 127:3979-3988.

40. Arning MD, Treu BL, Minteer SD: Citric acid cycle biomimic in an ammonium salt modified nafion membrane for fuel cell applications. Polym Mater Sci Eng 2004, 90:566-569.

41. Beilke MC, Minteer SD: Immobilization of glycolysis enzymes in hydrophobically modified Nafion. Polym Mater Sci Eng 2006, 94:556-557.

42. Aranaz I, Harris R, Heras A: Chitosan amphiphilic derivatives, chemistry and applications. Curr Org Chem 2010, 14:308-330

43. Scott K, Yu EH, Ghangrekar MM, Erable B, Duteanu NM: Biological and microbial fuel cells. Compr Renew Energy 2012, 4:277-300.

44. Virdis B, Freguia S, Rozendal RA, Rabaey K, Yuan Z, Keller J: Microbial fuel cells. Treatise Water Sci 2011, 4:641-665.

45. Moon $\mathrm{H}$, Chang IS, Kim BH: Continuous electricity production from artificial wastewater using a mediator-less microbial fuel cell. Bioresource Tech 2005, 97:621-627.

46. Kim BH, Chang IS, Gil GC, Park HS, Kim HJ: Novel BOD sensor using mediator-less microbial fuel cell. Biotechnol Lett 2003, 25:541-545.

47. Bond DR, Lovely DR: Evidence for involvement of an electron shuttle in electricity generation by Geothrix fermentans. Appl Environ Microbiol 2005, 71:2186-2189.

48. Davis F, Higso SPJ: Biofuel cells-Recent advances and applications. Biosens Bioelectron 2007, 22:1224-1235

49. Gülzow E: Alkaline fuel cells: a critical view. J Power Sources 1996, 61:99-104

50. Zaidi SMJ: Development of proton conducting composite membranes for fuel cell applications, PhD Thesis. Laval University; 2000.

51. Souzy R, Ameduri B: Functional fluoropolymers for fuel cell membranes. Prog Polym Sci 2005, 30:644-687.

52. Souzy R, Ameduri B, Boutevin B: Functional fluoropolymers for fuel cell membranes. Prog Polym Sci 2004, 29:75-106.

53. Feichtinger J, Galm R, Walker M, Baumgartner KM, Schulz A, Rauchle E, Schumacher U: Plasma polymerized barrier films on membranes for direct methanol fuel cells. Surf Coat Technol 2001, 142-144:181-186.

54. Li L, Zhang J, Wang Y: Sulfonated poly (ether ether ketone) membranes for direct methanol fuel cell. J Membr Sci 2003, 226:159-167.
55. Jung DH, Cho SY, Peck DH, Shin DR, Kim JS: Performance evaluation of a Nafion/silicon oxide hybrid membrane for direct methanol fuel cell. J Power Sources 2002, 106:173-177.

56. Yoon SR, Hwang GH, Cho WI, Oh $\mathrm{H}_{\text {, Hong }} \mathrm{SA}$, Ha HY: Modification of polymer electrolyte membranes for DMFCs using Pd films formed by sputtering. J Power Sources 2001, 106:215-223.

57. Ma ZQ, Cheng P, Zhao TS: A palladium-alloy deposited Nafion membrane for direct methanol fuel cells. J Membr Sci 2003, 215:327-336.

58. Choi WC, Kim JD, Woo SI: Modification of proton conducting membrane for reducing methanol crossover in a direct-methanol fuel cell. J Power Sources 2001, 96:411-414.

59. Kim YS, Hickner MA, Dong L, Pivovar BS, McGrath JE: Sulfonated poly (arylene ether sulfone) copolymer proton exchange membranes: Composition and morphology effects on the methanol permeability. J Membr Sci 2004, 243:317-326.

60. Jung DH, Cho SY, Peck DH, Shin DR, Kim JS: Preparation and performance of a Nafion ${ }^{\circledR} /$ montmorillonite nanocomposite membrane for direct methanol fuel cell. J Power Sources 2003, 118:205-211.

61. Smit EA, Ocampo AL, Espinosa-Medina MA, Sebastian PJ: A modified Nafion membrane with in situ polymerized polypyrrole for the direct methanol fuel cell. J Power Sources 2003, 124:59-64.

62. Shao ZG, Wang $X$, Hsing IM: Composite Nafion/polyvinyl alcohol membranes for the direct methanol fuel cell. J Membr Sci 2002, 210:147-153.

63. Zhou X, Weston J, Chalkova E, Hofmann MA, Ambler CM, Allcock HR, Lvov SN: High temperature transport properties of polyphosphazene membranes for direct methanol fuel cells. Electrochim Acta 2003, 48:2173-2180.

64. Guo Q, Pintauro PN, Tang H, O'Connor S: Sulfonated and crosslinked polyphosphazene-based proton-exchange membranes. J Membr Sci 1999, 154:175-181.

65. Arico AS, Baglio V, Blasi AD, Creti P, Antonucci PL, Antonucci V: Influence of the acid-base characteristics of inorganic fillers on the high temperature performance of composite membranes in direct methanol fuel cells. Solid State lon 2003, 161:251-265

66. Antonucci PL, Arico AS, Creti P, Ramunni E, Antonucci V: Investigation of a direct methanol fuel cell based on a composite Nafion-silica electrolyte for high temperature operation. Solid State lon 1999, 125:431-437.

67. Pivovar BS, Wang Y, Cussler EL: Pervaporation membranes in direct methanol fuel cells. J Membr Sci 1999, 154:155-162.

68. Jones DJ, Rozière J, Marrony M: High temperature DMFC stack operating with non-fluorinated membranes. Fuel Cells Bulletin 2005.

69. Bauer F, Porada MW: Microstructural characterization of Zr-phosphate-Nafion ${ }^{\circledR}$ membranes for direct methanol fuel cell (DMFC) applications. J Membr Sci 2004, 233:141-149.

70. Nunes SP, Ruffmann B, Rikowski E, Vetter S, Richau K: Inorganic modification of proton conductive polymer membranes for direct methanol fuel cells. J Membr Sci 2002, 203:215-225

71. Cohen SG, Wolosinski HT, Scheuer PJ: $\alpha, \beta, \beta$-trifluorostyrene and a-chloro - $\beta$, $\beta$-difluorostyrene. J Am Chem Soc 1949, 71:3439-3440.

72. Lin CW, Thangamuthu $R$, Yang CJ: Proton-conducting membranes with high selectivity from phosphotungstic acid-doped poly(vinyl alcohol) for DMFC applications. J Membr Sci 2005, 253:23-31.

73. Prober M: The synthesis and polymerization of some fluorinated styrenes. J Am Chem Soc 1953, 75:968-973.

74. Xu W, Liu C, Xue X, Su Y, Lv Y, Xing W, Lu T: New proton exchange membranes based on poly (vinyl alcohol) for DMFCs. Solid State lon 2004, 171:121-127.

75. Tevlina AS, Ivankin AN, Korshak W, Baranova NP, Nikitina TS, Rokhlin EM: Copolymerization of $\mathrm{a}, \mathrm{b}$, b-trifluorostyrene with some vinyl monomers. Viniti 1981, 12:127-181.

76. Karthikeyan CS, Nunes SP, Prado LASA, Ponce ML, Silva H, Ruffmann B, Schulte K: Polymer nanocomposite membranes for DMFC application. J Membr Sci 2005, 254:139-146.

77. Połtarzewski Z, Wieczorek W, Przyłuski J, Antonucci V: Novel proton conducting composite electrolytes for application in methanol fuel cells. Solid State Ion 1999, 119:301-304

78. Silva VS, Ruffmann B, Silva H, Gallego YA, Mendes A, Madeira LM, Nunes SP: Proton electrolyte membrane properties and direct methanol fuel cell performance: I. Characterization of hybrid sulfonated poly(ether ether ketone)/zirconium oxide membranes. J Power Sources 2005, 140:34-40

79. Wu H, Wang Y, Wang S: A methanol barrier polymer electrolyte membrane in direct methanol fuel cells. J New Mat Electr Sys 2002, 5:251-254. 
80. Manea C, Mulder M: New polymeric electrolyte membranes based on proton donorproton acceptor properties for direct methanol fuel cells. Desalination 2002, 147:179-| 82

81. Woo Y, Oh SY, Kang YS, Jung B: Synthesis and characterization of sulfonated polyimide membranes for direct methanol fuel cell. $J$ Membr Sci 2003, 220:31-45.

82. Zhang X, Filho LP, Torras C, Valls RG: Experimental and computational study of proton and methanol permeabilities through composite membranes. J Power Sources 2005, 145:223-230.

83. Chakrabarty T, Kumar M, Shahi VK: Chitosan based membranes for separation, pervaporation and fuel cell applications Recent developments. In biopolymers. Edited by Elnashar MM. India: Sciyo; 2010:201-226.

84. Yamada M, Honma I: Anhydrous proton conductive membrane consisting of chitosan. Electrochim Acta 2005, 50:2837-2841.

85. Lewandowski A, Skorupska K, Malinska J: Novel poly(vinyl alcohol)- $\mathrm{KOH}-\mathrm{H}_{2} \mathrm{O}$ alkaline polymer electrolyte. Solid State Ion 2000, 133:265-271.

86. Xiong Y, Liu QL, Zhang QG, Zhu AM: Synthesis and characterization of cross-linked quaternized poly(vinyl alcohol)/chitosan composite anion exchange membranes for fuel cells. J Power Sources 2008, 183:447-453.

87. Wan Y, Creber KAM, Peppley B, Tam Bui V: Ionic conductivity of chitosan membranes. Polymer 2003, 44:1057-1065.

88. Wan Y, Creber KAM, Peppley B, Tam Bui V: Structure and ionic conductivity of a series of di-o-butyrylchitosan membranes. J Appl Polym Sci 2004, 94:2309-2323.

89. Wan Y, Creber KAM, Peppley B, Tam Bui V: Ionic conductivity and related properties of cross-linked chitosan membranes. J Appl Polym Sci 2003, 89:306-317.

90. Wan Y, Creber KAM, Peppley B, Tam Bui V: Synthesis, characterization and ionic conductive properties of phosphorylated chitosan membranes. Macromol Chem Phys 2003, 204:850-858.

91. Wang J, He R, Che Q: Anion exchange membranes based on semi interpenetrating polymer network of quaternized chitosan and polystyrene. J Colloid Interface Sci 2011, 361:219-225.

92. Mukoma P, Jooste BR, Vosloo HCM: Synthesis and characterization of cross-linked chitosan membranes for application as alternative proton exchange membrane materials in fuel cells. J Power Sources 2004, 136:16-23.

93. Du J, Bai Y, Chu W, Qiao L: The structure and electric characters of proton conducting chitosan membranes with various ammonium salts as complexant. J Polym Sci Part B: Polym Phys 2010, 48:880-885.

94. $\mathrm{Ng}$ LS, Mohamad AA: Protonic battery based on a plasticized chitosan-NH4NO3 solid polymer electrolyte. J Power Sources 2006, 163:382-385

95. López-Chávez E, Oviedo-Roa R, Contreras-Pérez G, Martínez-Magadán JM Castillo-Alvarado FL: Theoretical studies of ionic conductivity of cross-linked chitosan membranes. Int J Hydrogen Energy 2010, 35:12141-12146.

96. Smitha B, Sridhar S, Khan AA: Chitosan-poly (vinyl pyrrolidone) blends as membranes for direct methanol fuel cell applications. J Power Sources 2006, 159:846-854

97. Choudhury NA, Ma J, Sahai Y, Buchheit RG: High performance polymer chemical hydrogel-based electrode binder materials for direct borohydride fuel cells. J Power Sources 2011, 196:5817-5822.

98. Klotzbach T, Watt M, Ansari Y, Minteer SD: Effects of hydrophobic modification of chitosan and Nafion on transport properties, ion-exchange capacities, and enzyme immobilization. J Membr Sci 2006, 282:276-283.

99. Klotzbach TL, Watt M, Ansari Y, Minteer SD: Improving the microenvironment for enzyme immobilization at electrodes by hydrophobically modifying chitosan and Nafion ${ }^{(8)}$ polymers. J Membr Sci 2008, 311:81-88.

100. Wu B, Zhang Y, Kuang Y, Yu Y, Zhang X, Chen J: Chitosanfunctionalized carbon nanotubes as support for the high dispersion of PtRu nanoparticles and their electrocatalytic oxidation of methanol. Chem Asian J 2012, 7:190-195.

101. Wang D, Lu S, Xiang Y, Jiang SP: Self-assembly of HPW on Pt/C nanoparticles with enhanced electrocatalysis activity for fuel cell applications. App/ Catal B-Environ 2011, 103:311-317.

102. Deng $L$, Shang L, Wen D, Zhai J, Dong S: A membraneless biofuel cell powered by ethanol and alcoholic beverage. Biosens Bioelectron 2010, 26:70-73.

103. Falk B, Garramone S, Shivkumar S: Diffusion coefficient of paracetamol in a chitosan hydrogel. Mater Lett 2004, 58:3261-3265.

104. Liu Y, Wang M, Zhao F, Xu Z, Dong S: The direct electron transfer of glucose oxidase and glucose biosensor based on carbon nanotubes/ chitosan matrix. Biosens Bioelectron 2005, 21:984-988.
105. Wei X, Cruz J, Gorski W: Integration of enzymes and electrodes: Spectroscopic and electrochemical studies of chitosan enzyme films. Anal Chem 2002, 74:5039-5046

106. Cooney MJ, Lau C, Windmeisser M, Liaw BY, Klotzbach T, Minteer SD: Design of chitosan gel pore structure: Towards enzyme catalyzed flowthrough electrodes. J Mater Chem 2008, 18:667-674.

107. Higgins SR, Foerster D, Cheung A, Lau C, Bretschger O, Minteer SD: Fabrication of macroporous chitosan scaffolds doped with carbon nanotubes and their characterization in microbial fuel cell operation. Enzyme Microb Tech 2011, 48:458-465.

108. Higgins SR, Lau C, Atanassov P, Minteer SD, Cooney MJ: Hybrid biofuel cell: Microbial fuel cell with an enzymatic air-breathing cathode. ACS Catal 2011, 1:994-997.

109. Katuri K, Luisa Ferrer M, Gutierrez MC, Jimenez R, Monte F, Leech D: Three-dimensional microchanelled electrodes in flow-through configuration for bioanode formation and current generation. Energy Environ Sci 2011, 4:4201-4210.

110. Liu X, Sun X, Huang Y, Sheng G, Wang S, Yu H: Carbon nanotube/ chitosan nanocomposite as a biocompatible biocathode material to enhance the electricity generation of a microbial fuel cell. Energy Environ Sci 2011, 4:1422-1427.

doi:10.1186/2043-7129-1-16

Cite this article as: Vaghari et al:: Recent advances in application of chitosan in fuel cells. Sustainable Chemical Processes 2013 1:16

\section{Publish with ChemistryCentral and every scientist can read your work free of charge \\ "Open access provides opportunities to our colleagues in other parts of the globe, by allowing anyone to view the content free of charge." \\ W. Jeffery Hurst, The Hershey Company.}

- available free of charge to the entire scientific community

- peer reviewed and published immediately upon acceptance

- cited in PubMed and archived on PubMed Central

- yours - you keep the copyright

Submit your manuscript here:

http://www.chemistrycentral.com/manuscript/<smiles>c1ccccc1</smiles>

ChemistryCentral 